\title{
Image of Mustapha in Fulke Greville's Mustapha (1594)
}

\author{
Fahd Mohammed Taleb Al-Olaqi \\ Faculty of Science \& Arts - Khulais, University of King Abdulaziz \& \\ University of Jeddah, Jeddah, Kingdom of Saudi Arabia \\ E-mail: falolaqi@uj.edu.sa
}

Received: 10-09-2016

Accepted: 13-11-2016

Advance Access Published: January 2017

Published: 01-03-2017

doi:10.7575/aiac.ijalel.v.6n.2p.63

URL: http://dx.doi.org/10.7575/aiac.ijalel.v.6n.2p.63

\begin{abstract}
The image of the historical Turkish Prince Mustapha (1520-1566) is symbolic in Elizabethan Age as a reflection of paternal filicide. The tragedy of Prince Mustapha is portrayed in many plays. It is a unique portrait of subjugation in the Elizabethan eyes of the European fear of Turkey. Although some historians envisage Mustapha with admiration for his tragic fate by the Turkish tyrant, Greville stands by the side of the Turkish prince. Greville's Soliman is an arrogant sultan with bloody hands who cares only for his crown. Roxolana is the evil sultana who plotted the demise of Mustapha to save the crown for her own son. By an irony of fate, Roxolana ends up a victim to her own plot. Though Greville expresses his allure in the Turkish court's affairs, he portrays his apprehension in the Turkish Sultan.
\end{abstract}

Keywords: Mustapha, Soliman, Roxolana, Zanger, Ambition, Treachery, murder, filicide

\section{Introduction}

The article studies the image of Prince Mustapha in Fulke Greville's The Tragedy of Prince Mustapha, Son of Solyman the Magnificent (1594). Soliman's execution of Mustapha became an ultra-popular topic in sixteenth-and seventeenthcentury European literature and drama, spawning numerous English tragedies such as Greville's Alaham (c. 1600), Roger Boyle's The Tragedy of Mustapha (1668), William Davenant's The Siege of Rhodes (1656), and the Early of Orrery's Mustapha (1664). These plays contain the same story of Mustapha with much attention to the performance of Sultana Roxolana as a major female player in the Ottoman Empire's policy. Karen Raber, a literary critic, who has come across closely into Greville's life and plays, argues:

Greville's literary work self reflexively ... investigates the dangers to the political hierarchy and theories of good rule posed by the familial relationships of all-too-human kings... Greville's closet dramas repeatedly focus on monstrous women at the heart of the familial/political nexus. In this fashion, they put gender at the root of monarchy's frailty ... and the particular problems created for English subjects by Elizabeth I's ambiguous status - a prince who characterizes herself as father and mother, lover and leader, spouse and parent to her people (Raber, 2001: 113).

The latest Ottoman personage to be dramatized in Renaissance drama is Mustafa, Sultan Soliman son, in Fulke Greville's Mustapha (1594). The play is a closet tragedy intended to be read, rather than acted on stage. Turks were seen to be "different and strange, infidels and 'barbarians,' admirable or fearsome," but they did not constitute "colonial targets" (Matar, 1999:2). The play reveals his concern with political matters in the Elizabethan Court in which Greville was a victim of political oppression. It is written about the closing years of the reign of Soliman the 'Magnificent' and the murder of his eldest son Mustapha. In 1553, Soliman caused the death of his son Mustapha under the influence of evil counsellors and his wife Hurem (Khourrem). This was an act that exemplified 'Turkish cruelty' (Knolles, 1701:760). For many Englishmen in the sixteenth and seventeenth centuries, the story is a fascinating illustration of the history of Turkish Orientalism. The reoccurrence of several Ottoman royal issues in English literature like Greville's Mustapha makes the Turkish Orientalism a perfect material for reading and teaching the Oriental Other. The story of Mustapha was popular and widely known in Europe. Also, the play served as a major source for many historical and literary texts, composed subsequently to this text. Western chroniclers repeated tales of wickedness and cruelty inflicted by the 'scourge of God' that portrayed the inhuman cruelties practiced by the Turks (Chew, 1965:14). Louis Wann divides Elizabethan period into four main phases in which the second phase, extending from 1586 to 1611 , is clearly the most significant one since 32 plays out of 47 were written in this period (Wann, 1915: 424-426). The fascination with the Ottoman Empire led even the significant English playwrights of the period such as Marlowe, Greene, Peele, Dekker and Shakespeare to write plays dealing with the Turkish oppression.

The most popular theme of some plays about Mustapha involves, the eldest son of Roxolana and Soliman. Mustapha posed as an obstacle to Roxolana's ambitions of her own son to succeed Soliman. This is the most popular and influential plot summary recurring in plays starring Roxolana that appeared in sixteenth-and seventeenth century England. It is indeed a remarkable story involving a struggle for survival in a dangerous world-rich in dramatic material 
for the English stage. Many source books about Turkey were available for writers such as Danad's da Lezz's Historie Turchesca (1513), The Policy of the Turkish Empire (1597), Peter Aston's A Short Treatise upon the Turks Chronicles (1564), and Hugh Gough's The Offspring of the House of Ottomans (1553).

\section{Greville's Prince Mustapha}

The Tragedy of Mustapha brought a great reputation to Greville. The play is a paradoxical depiction of the political life of the author Greville who resembles Mustapha as a political victim. Greville is generally regarded by historians of the period as 'the very prototype of the gentle courtier' (Mathews, 1966: 291). Greville is a man who treated 'all classes of men' with respect and courtesy. He is described as a brave, affable, charming, humorous and generous man of intellectual and artistic genius who possessed such elegant speech that Bishop Corbett, who knew him well, claimed that his 'every word was wine and music'(Ibid.). Greville's Prince Mustapha has nobly succeeded and won the hearts of Soliman's army by virtue and action. Mustapha's tragedy proves that political uncertainty about his royal status is a symptom of a larger political disease, one which threatens the very stability of the state.

The tyranny of the father Sultan Soliman appears in Thomas Kyd's Soliman and Perseda. Sultan Soliman has excessively killed many Christians and members of his Ottoman family. The reference to the historic murder of Soliman to Prince Mustapha in 1553 is purposely symbolized in Soliman's killing of his brother Amurath in Soliman and Perseda to host his violence which has taken a lot of sympathy to Mustapha in Elizabethan London: "Mark well what follows, for the history / Proves me chief actor in this tragedy" (III.1, 49-50). The scene ends up with heavy Ottoman royal bloodshed. Fulke Greville has depicted the dramatic story of Soliman and his son Prince Mustapha from first wife and legal successor to receive power after him. Mustapha is recognised as the most talented of all his brothers. He is marvellously well-educated and prudent. Mustapha may have been Soliman's favorite, but the situation mysteriously changed because of Roxolana's plotting. The same historical event of Mustapha is dramatized in Greville's Mustapha. The horrible act and wicked offence of Sultan Soliman of murdering his eldest son Mustapha in 1553 is the plot of Greville's Mustapha (1596). The Elizabethan audience was keen on the story of the Turkish Mustapha. He was victimized enough to gain the Englishmen's sympathy (Fisher, 1974: 120). Greville's The Tragedy of Prince Mustapha, Son of Solyman the Magnificent depicts the force and the roles of various cultural and political representations in the ever-changing discourse about the Ottoman court.

The patterns of fratricide and patricide reveal themes of the unnatural Turkish family. They are examples of the delocalization that reflect a deep engagement with issues from the historical literature about the Turks (Tibbs, 2003:27). Vitkus remarks that "the Great Turk became a European bogey partly on the strength of a dynastic track record of executions, poisonings, strangulations, and general familicide" (Vitkus, 2000:18). The historical Turkish Prince Mustapha is not entirely an innocent victim whose misfortune makes him pitied against one of the ablest woman ever known in the Ottoman harem. There had been signs of tension between Sultan Soliman and Mustapha long before the increasing support of his supporters including the Turkish army and a provoked plot by the Roxolana's faction. Though Mustapha was favored to be the next sultan by his faction, this was not necessarily what Soliman had in mind to execute him. The history of the military and governorship appointments of Soliman's sons provides a rather interesting piece of evidence in this regard. Traditionally, the son favored by the sultan as heir apparent would be appointed to govern the southwest province of Manisa, which was closest to the capital. Mustapha governed Manisa between 1534 and 1541 (Attl, 1998:98). But in 1541 he was appointed to govern the rather remote province of Amasia in eastern Turkey. In history, Prince Mustapha was accused of conspiracy with the Persian king's daughter, and he was consequently strangled by the Turkish mutes in front of his father.

The historical son-killing crime of Soliman had brought disgrace on Soliman's long reign that bestowed him with the reputation of the greatest Ottoman emperor. In a murder plot controlled by Soliman's second wife, Roxolana, Mustapha was executed to safeguard the Ottoman monarchy for her progeny. The events led to the death of Roxolana's youngest son, the hunchback Tzhihanger, who was close to his step-brother. When her eldest son later died of unexplained causes, she supported the succession of her rebellious son Bajazet. As Soliman preferred the younger Selymus, tensions grew between father and son and culminated in Bajazet's leading a rebellion against his father. In 1555, Roxolana managed to reconcile father and son. But two years after her death, Bajazet revived his rebellious ambitions. The Persians, to whom he fled for assistance, imprisoned and delivered him to his father, who summarily ordered his execution (Ballaster, 2007:59-61). Nevertheless, many accounts of Mustapha's tragedy are based on unsubstantiated gossip and speculation, and it is possible that the roles of Roxolana and her son-in-law Rustem in this affair have been greatly exaggerated in English literature, particularly the Elizabethan Drama (Rogers and Ward, 1988: 21.).

Fulke Greville's Mustapha (1609), focused on the dynastic ramifications of the Mustapha story and portrayed Roxolana as a ruthless political villain. In some ways, the play demonizes her more than early modern historical accounts. In Mustapha's political tragedy, Europeans saw a warning against a powerful female whose machinations brought about a violation of the law and state order (Inalcik and Kafadar, 1993: 120). Such a view was prevalent in most historical works on Turkish matters of the sixteenth and seventeenth centuries. Therefore, Greville places much emphasis on the bewitched Suleiman's violation of the Islamic law when he married Roxolana. Greville stresses her cruel heart and her use of magical potions with which she weakened the Sultan's will. The gruesome details of the Turkish violence in this drama prevail in most of the European accounts of the tragedy.

\section{Greville's Soliman and Roxolana}

The historical Sultan Soliman I, is known as "the magnificent emperor of the East" as well as the "law maker" 
(Merriman, 1974: 96). His reign represents the most glorious period in the history of Ottoman Empire. During the course of his substantial extension of the Ottoman Empire from Baghdad to Budapest, he defeated and killed King Lewis of Hungary at Mohacs in 1526, taking Buda (Budin) in 1529 which has an attendance in the episodes of Greville's Mustapha. Buda, the Hungarian capital, was the southern "line of fortresses" of the Kingdom of Hungary, and after a heavy defeat, Soliman used Buda area in 1526 and 1529 as a territory of the allied kingdom and did not annex it fully to the Empire (Rogers and Ward, 1988:78).

The imperial adventure of Soliman in Europe became a fertile pasture for budding English playwrights to draw onward themes for their plays. Most historians were equally kind to Soliman, often portraying him as a great sovereign whose tight grip over the West and his justice led to the growth of the Ottoman Empire. In executing Mustapha, however, Soliman seemed to revert from - magnificence to the alleged norm of - Ottoman cruelty, thus, doubly reinforcing the stereotype. In Greville's Mustapha, Sultan Soliman appears in his greatness. He is all ears to Roxolana. He values her wisdom as highly as her charms and took counsel with her on every matter. She was in fact an empress.

Greville portrays Suleiman as a mere puppet in Roxolana's. She used to appoint Turkish lords and officers in charge in the Turkish Empire. She intervenes in the foreign policy as her ill-treatment with Hungarian royal family. Nonetheless, Soliman does not want Roxolana to set off the regional stability by making the Cross clash with the Crescent (Mustapha, 2.65). Soliman avoids the Christians' vengeance, though, they promise love for Turkey. Greville's image of Roxolana is a cross-cultural and transnational of her figure as she represents the exotic female Other (Note 1). Roxolana, in this respect, is like the Orient itself-less a historical figure than an amalgam and a site of various cultural fantasies and constructions. Roxolana appears in many literary works beyond the Elizabethan age such as in Jean Racine, Bajazet (1672); Nathaniel Lee, The Rival Queens (1677); Daniel Defoe, The Fortunate Mistress or Roxana (1724); and Charles Johnson, The Sultaness (1717) (Note 2).

\section{The dreadful Killing of Mustapha}

The paternal filicide is a disgrace in the historical career of Turkish emperor Soliman. For many Elizabethan analysts, the dynastic feud was destructive for the peace of the Ottoman Empire which became evident in the wake of Mustapha's death. Zanger, the son of Roxolana, is a bosom friend of his half-brother and rejects his mother plot to have the title of Heir apparent. The plan of Soliman to kill his son without a trial is woeful. It produces bloody play with a deceitful episode to inject real horror into a tragedy. The plot is intertwined with two witnesses 'ready to accuse him $\backslash$ Of treason done against your mightiness, \And then he shall be doomed by marshal law' (Mustapha, 4.247-9). Sultan Soliman could not overcome his jealousy from the ultimate loyalty of the Turkish army to Mustapha, for which Mustapha is eventually prosecuted. Soliman wants Mustapha murdered as a rival contesting his authority.

The murder of Mustapha is a notorious accident in the Ottoman Empire. The story is very colorful and dramatical. Roxolana has developed her ambition to keep power in her own progeny. When Roxolana first appears in Greville's Mustapha, she is in the midst of accusing Soliman's potential heir, Mustapha, as possessing a "strange aspiring minde" (1.31). It is indeed a serious charge of deceitfulness. She knows that the necessity of recognizing one's position is the governing principle of an orderly state and that along those lines "ambition becomes the most dangerous - and one of the most sinful - of all passions" (Craig, 1936:20). To convince Soliman that Mustapha is ambitious enough to overthrow him from power, she attempts to arouse his fears by questioning and casting doubt about Mustapha's attitude towards Persia, the Empire's traditional enemy, which proposes peace to Mustapha rather than to Soliman. She further suggests that Mustapha's current courting of the masses in hope of their support means nothing other than that he is impatient to succeed his father. But she flatters and reassures Soliman that Mustapha's attempts are futile in the face of his magnificence, yet cautions that he owes it to his state to protect himself and maintain order. Roxolana creates a problem, magnifies it, and then offers her counsel.

The only safe policy, according to Roxolana, is to kill Mustapha immediately. In the beginning, Soliman is shaken but not convinced. In the first few scenes, Roxolana has managed to convince Soliman that Mustapha is a threat to the throne. Yet, Soliman is not dubious about her plan to kill Mustapha, because of the difficulty of justifying his son's murder based merely on actions that, up to this point, are only potential. In this first scene, Roxolana is determined and bent on her will, a will sharply opposed to Mustapha's interests. She manages in the first scene to foment in Soliman's feeling of insecurity as well as a fear of losing control of the state. The scene also introduces two possible sources of that threat: Mustapha and Roxolana. Therefore, when Soliman has refused, she and her accomplice, Rustan, maliciously plotted the destruction of the hopeful young heir and planted suspicions in Soliman's mind. Rustan was wholly under Roxolana's control; he was a miser, false and wholly venal, who corrupted the entire state by selling its chief offices to the highest bidders, men who naturally sought to recompense themselves by every method of extortion. The plotter Rustan has preferred to convince Soliman of killing Mustapha.

Meanwhile, the episodes of The Tragedy of Prince Mustapha focus on the powerful beautiful Roxolana who strives to procure the crown to her own son Zanger after his father Sultan Soliman. Roxolana's jealousy from Mustapha's role in the Turkish Court creates the conflict in the political order. She works to be the absolute power after Soliman. Roxolana learns from Soliman that "In Kings the secrets of Creation rest," (Mustapha, 4. 132.) with reference at once to his physical, paternal power over his son and to his spiritual reflection of God's power in an earthly throne. But it is Roxolana who exploits the abyss between these two types of power. She constantly whispered in Soliman's ear hints about his son's treachery. Roxolana as represented in the play is fully aware of and willing to assume the whole Ottoman privilege: 
My chiefest end,

Is, first to fix this World on my Succession;

Next so to alter, plant, remove, create,

That I, not he, may fashion this Estate. (4.121)

Although Mustapha's existence means suffering for Roxolana, being torn by incompatible jealousy, Roxolana's subjectivity and consequently her intellect and emotion could be constructed to reach to the absolute power. In doing so, she takes over the "metaphoric apparatus of kingship, she takes on the role of the cultivator who tends to the garden of the country who plants, prunes and harvest.

The premeditated plotter of the murder of Prince Mustapha is Roxolana. She admonishes him when he seems to falter: "Be not a history to aftertimes / Of such ingratitude unto thy son" (4.15-16). Moreover, at the end of act three she soliloquizes over her dilemma in which she weighs the consequences of her disrupting the natural course of succession to Soliman's throne, a far cry from the Roxolana with a clear purpose:

With noble Zanger Mustapha contends

They strive as Rivals, and they yield as Friends.

I injure one if I the other choose:

And keeping either I the Sultan lose. (3.93-96)

Greville's play dwells on Mustapha as a guiltless sufferer by Roxolana's evilness and her sinister plan to execute her ambition. There are a lot of events in this play that leads to distract her after having entertained the thought of her pitting one brother against the other. One does not cringe from Roxolana's deeds, but rather helplessly admires them. She is a royal mother committed to protecting her own son's future and safety without an inch of selfishness (Mustapha. 1.2.77). Soliman was deceived by his loyal consultants, Rustan and Pyrrhus. First Rustan and Pyrrhus acquaint with father that his son is a smart leader in the Turkish army. Therefore, Soliman looks at Roxolana as out-watched jealousy from a step-mother. Soliman thinks if Mustapha usurps, he shall forgive. Although Roxolana tries to show herself impartial, she does not see in his eldest son that he may show faults, which others must not do it. She insists that the heir's nature will tell Soliman how far in his son, her husband ought to pardon any gallant crime. Consequently, Roxolana stirs off the emotion of jealousy in awakening the valiant power. There is no hope to live with this emotion of jealousy. On the other hand, Rustan and Pyrrhus changed their attitudes to entertain Roxolana's ambition.

The second scene then seeks to reveal the real threat. Roxolana has managed to diminish the fears she has planted in the Sultan. She simply states the obvious: she and Mustapha cannot both be innocent, plunging Soliman into the dilemma of deciding between wife and son (Raber, 2001:115). What she suggests through this argument is that Soliman's trust in Mustapha translates into distrust in her and denial of her love. Her logic is faulty, for it is based on the false premise that Soliman and Mustapha cannot both live; one must kill the other. The Sultan tries to avoid her question, but she pushes further into the consequences of what is to become of her if Soliman does not take action against Mustapha; he will end up being killed by his son, and she will lose a beloved husband and her status as sultana. Her legitimacy depends upon Soliman's remaining sultan. She manages to foster her husband's distrust in his son, through his fear of his own mortality. She shows him that his son is to him death incarnate, for succession teaches the monarch that he is mortal, and Mustapha is speeding up the process (Mustapha, 2.83-91, 122-24).

Roxolana is cautiously plotting to "alter Empire and Succession" (Mustapha.5.28). Roxolana serves as the Sultan's "alter ego, his dark and ugly side that expresses thoughts he can barely acknowledge" (Raber, 2001: 135). Yet Soliman refuses to turn completely against Mustapha. He, instead, maintains an attitude of watchful waiting that lends his character integrity and poignancy in the face of his wife's attempts at rash actions. Roxolana's audacity contrasts with his weakness, and her ability to make instant, unchangeable decisions highlights his prolonged uncertainty. She plunges him into a frenzy of questions about the ties of family, the ties of the state, the relevant duties of a subject to his monarch, and a son to his father (Mustapha, 1.9-17). To drive her point home Roxolana urges Rustan to design the episode of killing Mustapha. She asked Rustan to refresh intelligence to charge Mustapha with some new offence of treachery to Persia which proves persuasive for Soliman. At the beginning Soliman's parenthood is natural to Mustapha but Soliman's paranoia of his elderly son's popularity among the Ottoman army is intensified. He accuses Mustapha with gaining the love of the armies which is a destructive error and loss to the Sultan's state. Out of Roxolana's pressure, Soliman starts to perceive this type of love from the army to Mustapha as a crime: "Him whom they love, they still most worthy deem" (II).

Mustapha feels the suspicion of his father about his rising popularity among the Ottoman armies. Consequently, Mustapha attempts to keep away from his father by going to Syria. The prince is mentally ill since he cannot bear his father's hate. Rustan thinks sending Mustapha's expedition to the East to Persia is not an exile, but for fame. The prince is quite confident to do it with his great army. He thinks the task to gain Persia is vain since he is losing his father. Sultan Soliman's mode of distemper appears for Mustapha as a feeling of hate. Thus, Mustapha decides to obey his father's orders and submit. Soliman imagines Mustapha's ambition for glory shall overthrow him. Soliman says, 'He threatens me worse than a Comet here' (4. 84). Soliman considers changing Mustapha's doom. He promises to reckon 
what is past, and what may come from his son. Soliman is now full of psyche to plan an angry fate. He says:

Go, I'le consider e're I change his doom;

I'le reckon what is past, and what may come.

Oh Roxolana! Fate in vain bestows

Continual Conquests o're my open Foes;

Whilst it a tumult raises in my brest,

Fiercer than all those Wars I have supprest.

Justice perswades what nature fain would shun.

Pity a father who must hate his Son. (4.78-85)

For Soliman, Mustapha must be deprived of life, and his death may save Zanger to be the coming heir. At the same time, Roxolana vows that her son Zanger should reign after his father, which will make her the mother of the Empire's Heir. Roxolana turns sinful and unjust. She has planned to make Soliman kill his eldest son by her contrivance. She claims in shedding the blood of Mustapha she will save her offspring in power, and then, she will answer her guilt by washing away the blood stains of what is spilt (Act 4.106). She resembles Lady Macbeth to clean her hands from the blood of Duncan.

Roxolana's son, Zanger, does not believe in the worse to break down his ultimate friendship to his brother Mustapha. Zanger confesses his love for Mustapha makes himself enslaved. Mustapha acknowledges his brother's love and friendship. Zanger approves Mustapha as the Heir to the Ottoman Empire. Zanger loves Mustapha as his eldest and thinks that no one should violate Mustapha's right.

Zanger shows secret sympathy with the rumours of Mustapha's treachery. Zanger describes his feelings, if any bad action happens for his brother, his breast would feel it as soon as Mustapha's. This simile shows how tightly the relationship between the two brothers is. Mustapha appreciates Zanger's ultimate friendship which is a perfect praise between friends and rivals too. Greville is imagining a more "civilized" bargain made between the brothers to disregard this custom, and a promise not to murder one another if offered the throne. The brothers even agree to actively support one another:

Mustapha: By our great Prophet solemnly I swear,

If I the Turkish Crown do ever wear,

Our bloody Custom I will overthrow;

That Debt I both to you and Justice owe.

Zanger: And her I vow by all that good and high;

I'll not out-live the Day in which you die;

This which my Friendship makes me promise now,

My Grief will then enable me to do. (4.98)

Roxolana perseveres her plot of preserving her own son Zanger's supremacy over Mustapha and his succession to Soliman's throne by questioning the legitimacy of Mustapha's claim to the throne. Roxolana refers to the changeable and stained source of blood in Mustapha's absent mother:

The knowledge who was Father

To Mustapha made me (poor silly women)

Thinke worth in blood had naturall succession:

But now I see Ambition mixtures may

The gold of Nature's elements ally.

His fame untimely borne: Strength strangely gather'd

Honnor wonne with honoring, Greatnesss with humbleness,

(a Monarchs heir in courses popular,)

Make me divine some strange aspiring minde;

Yet doubtfull; for it might be Art, or Kinde. (4.45-54)

Here Roxolana feels that the name of Mustapha infects her breath. She stirs up a fundamental unsteadiness of the fatherson bond by questioning the untested and suspicious chastity of Mustapha's dead mother, referring to mixed elements and alloys, and to premature birth. She casts doubt over the son's "kind" altogether, entailing that he is no natural successor to his own father. She can thus manipulate Soliman further by carrying into enquiry Mustapha's birth and parentage, and consequently his right to natural succession to the Ottoman throne. She makes Soliman query the very predictability of his "natural succession." Roxolana's representation as a much softer and more feminine, and intelligent 
image is replaced with a ruthless schemer, murderer and yet deceitful.

Greville raises questions about the Ottoman's attitudes over their practice in phenomena of conspiracy. He has put his attitude in the mouth of the Queen of Hungary. The Queen points out that deceit is not seen as a Christian virtue, and for this reason, according to Roxolana, it is no wonder that the Hungarian monarch was killed and his infant heir was imprisoned, and that "Christian Kings live not in Courts but Cells" (2. 78) for not resorting to deceit when necessary only show but "ill-bred Innocence" (2. 78). She should know her story is one of survival, and ethics are also questioned by her. Roxolana points out to the virtuous Hungarian Queen, that deceit is necessary for survival, and not based on selfish endeavours but it is based on ambition, so she advises the Queen of Hungary to take on false appearances for the cause of her safety and her son's, as well as for the cause of her disintegrating nation. These two women are united as faithful, strong and courageous mothers, and in no point does the play demoralize or overthrow their positions. They come through as mothers who hug their domestic roles as caregivers and do what they have to do for continued existence. And in this play it is Roxolana who laments this custom of violence - the historical Roxolana who was thought to have prompted the very custom and endorsed it. Here is her grief:

Oh cruel Empire! That does thus ordain

Of Royal Race the youngest to be slain,

That so the eldest may securely reign;

Making the 'Imperial Mother ever mourn

For all her Infants in Succession born. (2.76)

She puts in that the imperial Turkish tradition is nothing but "Of fatal strife, where Victors nothing gain" (2.2.76) and some, who had killed their sons, more tears did shed for their own guilt, than that their sons were dead: Guilt wrought by Fate, which had the valour mov'd/ Against that Prince whom they for valor lov'd. (2.110).

Roxolana is malevolence as Shakespeare's Iago in Othello with a far cry from the static Lady-Macbeth-like (Almas, 2009:143) Roxolana evokes the female villains. While Greville's Roxolana is extreme of evil, manipulating the king and plotting his downfall, monstrous in part precisely because she is a woman, she is also a vehicle of political and philosophical commentary. In Mustapha, Roxolana designs to "alter Empire, and Succession" (Greville, Mustapha, 1990: 155), by convincing Soliman that his son Mustapha, is guilty of treachery, thus making her own son successor to the Ottoman monarchy.

The Sultan's investigation about the treason of his son is weak and not independent. He concluded with the accusation that Mustapha has a drastic ambition to overthrow him and forget the natural parental ties. Soliman thinks that his son is opting for a coup d'état as did his grandfather Selim. Soliman has to make an emergency action to save his reputation as a super monarch. Therefore, he over-reads the political situation with his son treachery that his European and Persian foes might storm Turkish towns. He thinks that the Turkish army will perform less since it is in the hand of Mustapha. Soliman is not going to stay idle to see Mustapha ascend his throne. Consequently, The Sultan gives the order to Rustan to kill Mustapha as a punishment by law. In this episode, Greville has figured out a mandate from the Islamic jurisdiction to approve the death sentence in reference to the Turkish law. Roxolana seems happy by this decree. She supports her husband by saying that excess of justice turns to cruelty. She reminds Soliman that if Mustapha is not punished, he would ruin him. Soliman is now resolved in his decision. He has forgotten his paternity compassion.

Mustapha's understanding of the matter is as it is a case of detestation not an offence of treason to depose his father. When he passes the guards and others shake their heads with sorrowful looks. He describes the guards when they have shaken their pensive heads as if they did dislike his destiny. Mustapha says:

All shake their pensive heads in passing by

As if they did dislike my destiny.

Let him dispatch whom he intends to kill:

'Tis less to suffer death then fear it still.

Nor is the worst of deaths so bad a Fate

As still to live under a Fathers hate. (5. 34-39)

Mustapha thinks that his torments are so many and so high and only death can be his remedy. He describes death will remove his father's jealousy and free him ever from his father's negligence. Mustapha thinks that his death will put an end of being a rival to his brave friend and brother Zanger. Mustapha deeply raises his concern though his death is comfort yet it will bring too sorrow for his bosom friendship with his brother. In Mustapha's death, the friendship of the two brothers will be appreciated as symbolic.

In the death scene, six mutes advance to kill Mustapha. One of them advances before the rest and kneels down, delivers Mustapha a black box with a parchment, the Sultan's great seal hanging at it in a black ribbon. Then he holds up a bowstring and makes signs that he should kneel and submit to the Sultan's sentence of death. The Sultan's law and order in the Turkish Empire is his priority. At the same moment, Soliman shouts at Mustapha, 'O Traitor!' At the first hearing of Soliman's voice Mustapha kneels and at the end of Soliman's speech, Mustapha lays at the Sultan's feet. In this confrontation, the Sultan accuses his son of treachery to sweep him from the throne. Mustapha is unable to save his life 
by proving his innocence. Unfortunately, Soliman does not allow his son to plead. He has permitted the killing of his eldest son in cold blood.

Mustapha is determined to accept the sentence to satisfy himself. He unjustly yields to his father's will without defence. He teaches the world to doubt his innocence and draw a spectacle to his father. Mustapha obeys the command. He goes with the Mutes for execution and Soliman looks after him whilst he is in sight. Soliman's heart moans for what his tongue commands. The Sultan thinks that his deed is against nature. The mutes slaughter Mustapha. In the killing scene Mustapha rises and pretends too guilty since Soliman thinks he is so. Soliman replies that though justice takes his son's life, he must lose because of his treachery. Mustapha succumbs to his fate heroically - a proof to his innocence since by his death he would remove his father's hate and gain his love. The scene shows that Turkish Astana unjustly runs atrocious acts by the name of laws though in the earlier scenes, the Sultan shows the qualities of magnanimity and courteousness as they are known in Europe.

The death of Mustapha is tragic. It makes everyone weeps. The guards are doubled everywhere and they feel grief and danger. Roxolana's woman, Zarma is shocked by the news of Mustapha's killing. Haly and she grieves and morn his demise. Haly finds that it turned their blood to tears when he did pray to all, in vain, to take his life away. Zanger is also shocked by the news of killing his dear brother. He sees the world bereft of much more virtue than is left in it. It was jealousy, not his horrible mistake which did so many months keep you awake (5.105), and it was just that you, who in your Breast would jealousy admit should take no rest. Zanger's speech is by this object overcome. Zanger goes towards Mustapha. He cries out: 'Ah Loyal Prince! Till death does close my Eyes, \Accept these Tears, my Friendships Sacrifice!' (3.52). Zanger points out that the cause that made Mustapha accepts his death in order to show his love against his father's hater. Zanger concludes that death is the only blessing he can find. Zanger criticizes his father's awful deed which he thinks unjust, and Zanger shall think it unfair. Zanger will rejoin Mustapha's world. Zanger accuses Rustan and Pyrrhus behind his brother's death. He says that 'Death is eternal in this evening' (4.13). He thinks that if Mustapha had known himself guilty, he would have escape to Syria.

Soliman is embarrassed by this information as Zanger was also behind Mustapha's black designs. Soliman accuse his second son as his sympathy shows him as guilty as Mustapha. Soliman asks him to desist, or he will share Mustapha's unjust fate. Zanger sets an example of Mustapha's rival in his love to the Hungarian Queen. Zanger states that nothing could prove more for his trust in friendship. They both loved the Hungarian Queen. Zanger says that Mustapha knew about Zanger's first pretensions. He freely confessed he loved her too. Soliman ponders over the reason of the Turkish army's applause for Mustapha as he has brought Victory to the army. Zanger comments that applause is the soldiers' error and not his brother's appearance. Zanger assures to his father that Mustapha was unhappy with the army's praise. For Zanger, Mustapha was faithful as the Viziers of the Sultan, who have been false and wrought Soliman into wrong suggestions about Mustapha's. By hearing this, Soliman is strongly shocked by this information saying, 'Oh Heaven! My guilt now makes it an offence To hear untimely of his innocence' (5.114). It is so late for Soliman to realize the truth which now turned to a torment.

The interest in this brotherhood friendship is exciting in Greville. Zanger reveals to his father that he religiously swore if something bad happen to Mustapha he would not out-live the day. Therefore, Zanger turns to his brother and says:

'Twas only love had strength enough t'invade

That mutual Friendship which we sacred made:

But now o're love I have the conquest got;

Though Love divided us, yet death shall not.-( Mustapha, 5.110-3)

Zanger stabs himself to death out of sorrow and falls at Mustapha's feet. The father runs to him and cries out to Zanger to hold. Zanger explains that the happy wound is given which sends his soul to Mustapha in Heaven. Now Zanger thinks that all he had to do on earth is done. He turns again to Mustapha and before he dies, he says 'Lo at your Feet, dear Friend, your Brother lies; \And where he took delight to live.' Zanger dies. The bodies of the two princes are lying in the court of their father.

In this horrific last scene of dead sons Soliman has lost his mind. Greville describes the moment as that their fame will adorn their shrine in the Christian Temple of Marry. He admits that this legend of the ottoman princes is not in Roman civilization (5.115). The author predicts the collapse of the Ottoman Empire as Soliman would die too, but by revenge. Soliman grieves and turns to Mustapha saying: 'Oh Mustapha! The worthy may in thee the dangerous state even of great virtue see' (5.116). The father has punished Mustapha for being very faithful in his love for him. Soliman remembers Mustapha's mother who was the first that ever possessed his heart. She was "the brightest beauty, and the softest wife" to Soliman who now fails to save Mustapha's life (5. 117). Before coming to the death scene, Roxolana is happy that the great deed is done. She perceives that she has been cruel to preserve her son Zanger, the Empires Heir. She hopes the Heaven surely forgives her since it rewards her care. The scene quickly changes when Roxolana goes towards the scene, where she sees Mustapha and Zanger with his dagger in his hand, and then she starts back. Roxolana cries aloud on seeing both princes dead. She sorrowfully laments:

Both dead! O horror! Zanger does appear

Armed 'against himself as his own Murderer.

This deed Friendship and pity made thee do.

But was not I thy Friend and Mother too? 
That Friendship against Nature was a crime

Which paid me nothing and too much to him.

Though Friendship to a Friend thou might'st assign,

Yet, since I lent thee life, that life was mine.

Unjust to Nature, though to Friendship true,

In paying Friendships debt with Natures due.

Is this the last reward of all the pain

I felt, saving thy life to make thee reign?

Thou hast revenged (O Heav'n) what I have done

With so much guilty kindness for my Son! (5.150-162)

Soliman turns to murder his unfaithful aides. The scene goes disastrously with full of twenty four dead persons on the stage. Soliman sent Roxolana for life perpetual exile. He has deeply expressed his sorrow over her plot. He promised to forget her and her love forever. Roxolana begs him for forgiveness but Soliman declines her right and departs her forever. He has decided to lock his bosom up where his love for her does reside.

Roxolana's character in Greville's play justifies fears of woman's Oriental activity in issues related to the Turkish monarchy. As Karen Raber argues, through Roxolana and in keeping with his times, Greville "re-evaluates the threat that Elizabeth's gender represented to England" by having her embody "the internalized danger of femininity, the disruptive force within - the force that is the family, that creates family with all the consequent messy, unstable power relations between husbands and wives, parents and children" (Raber, 2001:137). Roxolana's life story, as it appears in sources that Greville is thought to have pulled from, provided convenient parallels to his anxieties that were ultimately reflected in his play. The psychological complexity and popularity of the Roxolana figure has undoubtedly contributed to the change of her image in the western imagination. From a scheming, murdering machine of the Renaissance historical accounts and Senecan plays, Roxolana is transformed into a truly tragic character, and the sensational nature of Mustapha's story is turned into a high tragedy of a great psychological depth, contrasting favourably with the harsh didacticism of the early Middle Ages. The tragedy which tarnishes Roxolana's triumph during this period is the death of her son Zanger. The young son was a charming person and a capable governor to rule Turkey. His death is evidently a deeply felt loss for her, and she expresses her grief very publicly. Soliman is watching the cruel bloody scene. The language of Soliman is also established to enhance his Turkish stereotyped brutality. Many characters are killed in the scene, when he is not a reinstated Grand Sultan in scene. The representation of the Turks is a terrible stereotype. Furthermore, Greville portrays the Turkish law as corrupt, unjust, evil, and ugly. Through this Turkish law tradition, Greville's Soliman has constantly breached the system of justice in using it to violate friendship's sincerity and kill innocent people.

It appears as if, particularly in this play, England is far removed from the world's political scene. There is an indefinite fear and anxiety from the Turks. The play appears to take a rather relaxed and contemplative look at the recent events that plagued England through the civil war, and packaged it in an interesting Oriental setting with legendary characters such as Soliman and Roxolana. Soliman's public image revolted against Turks. His disastrous violations to the Islamic laws and commandments by killing his innocent son led to a fracture in the Ottoman power. Indeed in the very end, after Mustapha is murdered, Soliman comes to the realization that monarchism should be absolute: "Blest Heav'ns King, who Monarchy first made, / And praised him, cause he no companion had" (5. 99-100). Both Roxolana and the Hungarian Queen act as the prognosticators in the play and warn of events to come. Sorrow and grief remains in the life and memory of Soliman. One of his poetic letters to Roxolana breathes his deep sorrow. He writes:

$$
\begin{aligned}
& \text { My very own queen, my everything, } \\
& \text { my beloved, my bright moon; } \\
& \text { My intimate companion, my one and all, } \\
& \text { sovereign of all beauties, my sultan. } \\
& \text { My life, the gift I own, my be-all, } \\
& \text { my elixir of Paradise, my Eden, } \\
& \text { My spring, my joy, my glittering day, } \\
& \text { my exquisite one who smiles on and on. [ ... ] } \\
& \text { My Istanbul, my Karaman, and all the } \\
& \text { Anatolian lands that are mine; } \\
& \text { My Bedakhshan and my Kipchak territories, } \\
& \text { my Baghdad and my Khorasan. (Note 3). }
\end{aligned}
$$

To sum up, Mustapha's death is considered by many Elizabethans the beginning of the end of the Ottoman Empire which was a legend for many Europeans. In Greville's Mustapha the inhumanity of the Turks was emphasized above all else, and the stereotyped Turk, villainous, savage and bloodthirsty, swooping down upon innocent Christians, and 
massacring them indiscriminately, was firmly established in the historical traditions of the West. As the West began to form its Asian Turkish fantasy, and as the "cruel Turk" image gave more room to the "amorous Turk" image, there also came a shift in the perception of Mustapha's tragedy. Greville shows to the Elizabethan audience the state of lawlessness and tyranny in Soliman's Turkey in sharp contrast to England.

\section{Conclusion}

The interest in Mustapha reflected the West's general fear of and fascination with the Turks. Greville's Mustapha really symbolizes a Renaissance humanist who rejects the brutality of the Turkish tremendous power. Mustapha ends with injustice to symbolize rebellious aspects of oppression. Mustapha is not the expected submitted soul. Not being a Turkish victim himself but a renovated one, Mustapha fits to represent the victim of the monarchical brutal state, which violates truces with alliances and carries out plots against the friend or the foe. Greville shows how the Eastern royal systems sacrifice the souls to save their sovereignty. For the Renaissance people in the early modern period, stereotypical features of the Turks included "aggression, lust, suspicion, murderous conspiracy, sudden cruelty masquerading as justice, merciless violence rather than 'Christian charity,' wrathful vengeance instead of turning the other cheek" (Vitkus, 2000:2). The dominant discourse, thus, "demonized” the Turks, with whom Islam was identified, not only by teaching and preaching but also through representations (or rather misrepresentations) in history books and public/private stages, as well as by social practices. This kind of "rigorous Christian picture of Islam was intensified in innumerable ways, including - during the Middle Ages and early Renaissance - a large variety of poetry and popular superstition" as well as stage representations (Said, 2003: 61). For the Elizabethan theatregoers, then, the Turk was not simply an imaginary "evil" but a nearing unchristian power threatening both their existence and religion. Seneca dramatizes moral insights; human soul and human behaviour under moral stress. Soliman has caused his own destruction with his arrogant behavior and extravagant lifestyle.

The image of the imperial Ottoman family is a prototype example of the whole Turkish Empire. It is an output of some European suffering from the Ottoman Empire subjugation. Hostility was behind the horrible criminal theme of Mustapha in Elizabethan London stage. In Greville's Mustapha, the theme of divine revenge on Roxolana and Soliman shares enough common characteristics with the writings of the Elizabethan drama in presenting the Turkish tragedies. In Greville's Mustapha the inhumanity of the Turks was emphasized above all else, and the stereotyped Turk, villainous, savage and bloodthirsty, swooping down upon innocent Christians, and massacring them indiscriminately, was firmly established in the historical traditions of the West. Seneca dramatizes moral insights; human soul and human behaviour under moral stress.

The misrepresentation of the image of Sultan Soliman in Greville's Mustapha has its impact on the production of Thomas Kyd's Soliman and Perseda which is a typical tradition for Elizabethan playwrights. It is the outcome of the terror from the Ottoman Empire amongst Elizabethan Europeans. The Turkophobia was behind the revenge theme on the stages of Elizabethan London. Taking vengeance of an Ottoman appearance was quite typical in Europe. In Kyd, the revenge theme from Ottoman Sultans shares enough common characteristics with the writings of Elizabethan drama (Al-Olaqi, 2013:52). Greville's Soliman has caused his own destruction with his arrogant behavior and extravagant lifestyle. Westerners had word of this fascinating palace intrigue through diplomatic correspondents who were not privy to the actual harem, and adopted the story themselves while imaginatively filling in the Orientalizing details. The scenario blending the familiar and the exotic - a European in the court of the Turk; a slave woman dominating the conqueror; fratricidal princes and the alluring seraglio - all set in the heart of the feared Muslim state proved irresistible to literary interlocutors. These made of Soliman, Mustapha, and Roxolana moral fables on theatre.

\section{Acknowledgement}

This work was funded by the Deanship of Scientific Research (DSR), King Abdulaziz University, Jeddah, under grant No. (857-001-D1434). The author, therefore, acknowledges with thanks DSR technical and financial support. Fahd Mohammed Taleb Saeed Al-Olaqi.

\section{References}

Almas, L. M. (2009). The Women of the Early Modern Turk and Moor Plays, a PhD dissertation available online at http://conservancy.umn.edu/bitstream/54043/1/Almas_umn_0130E_10589.pdf.

Al-Olaqi, F. (2013). The Oriental Other Soliman the Magnificent in Kyd's Soliman and Perseda TRAMES, 17(66/61), 2, pp.177-201. DOI: 10.3176/tr.2013.1.02.

At1l, E. (1998). The Age of Sultan Suleiman the Magnificent. Washington, D.C., National Gallery of Art.

Backsheider, P.R., and Ingrassia, C. (2006) A Companion to the Eighteenth-Century English Novel and Culture, Victoria: Blackwell Publishing.

Ballaster, R. (2007) Fabulous Orients: Fictions of the East in England 1662-1785 (New York: Oxford UP.

Brooke, C.F. (ed.) (1910). The Works of Christopher Marlowe, Oxford: Clarendon Press.

Bullough, G. (1945) Poems and Dramas of Fulke Greville (New York: Oxford UP). 
Chew, S. C. (1965). The Crescent and The Rose: Islam and England during the Renaissance. New York: Octagon Books.

Erne, L. (2001). Beyond The Spanish Tragedy: a Study of the Works of Thomas Kyd (Manchester UP).

Craig, H. (1936). The Enchanted Glass: The Elizabethan Mind in Literature, New York: Oxford UP.

Greville, F. (1939). Mustapha, in Poems and Dramas of Fulke Greville, Vol.II, edited by Geoffrey Bullough, Edinburg: Oliver and Boyd.

Greville, F. (1990) Certain Learned and Elegant Works, reprinted in New York, Scholars' Facsimiles.

Inalcik, H., and Kafadar, C. (eds.) (1993) The Life and Family of Suleyman I, by Alan W. Fisher, Istanbul, Isis.

Knolles, R. (1701) The Generall Historie of the Turkes, from the first beginning of that Nation to the rising of the Othoman Familie: with all the notable expedition of the Christian Princes against them. Together with the Lives and Conquests of the Othoman Kings and Emperours, London: printed by Adam Islip, 1603; reprinted with additional notes in $1610,1621,1631,1638,1679,1687-1700$ (3 vol.), 1701(abridged).

Lamb, H. (1951). Suleiman, the Magnificent, Sultan of the East. New York: Doubleday.

Matar, N. (1999) Turks, Moors, and Englishmen in the Age of Discovery. New York: Columbia U P.

Merriman, R.B. (1974). Suleiman the Magnificent, 1520-1566. Cambridge, Massachusetts: Harvard University Press.

Raber, K. (2001) Dramatic Difference: Gender, Class, and Genre in the Early Modern Closet Drama, Newark: University of Delaware Press.

Rogers, J. M . \& Ward, R. M. (1988). Suleyman the Magnificent. exhibition cat. British Museum Publications. New York, Tabard Press.

Said, E. W. (2003). Orientalism, London: Penguin Books.

Vitkus, D. (2003). Turning Turk: English Theatre and the Multicultural Mediterranean, 1570-1630. Basingstoke: Palgrave Macmillan.

Tibbs, S.J. (2003). Lineages of Turkish power in early modern writing in English Newcastle University.

Vitkus, D. (2000) Three Turk Plays from Early Modern England. New York: Columbia UP.

Wann, L. (1915). 'The Oriental in Elizabethan Drama', Modern Philology, 12, 423-47.

Yermolenko, G. (2005). "Roxolana: 'The Greatest Empresse of the East"” in Muslim World 95.2

\section{Notes}

Note 1. For a shorter account of Roxolana's life, see Galina Yermolenko's article, "Roxolana: 'The Greatest Empresse of the East"” in Muslim World 95.2 (2005): 231-47.

Note 2. See Paula R. Backsheider, and Catherine Ingrassia, A Companion to the Eighteenth-Century English Novel and Culture (Victoria: Blackwell Publishing, 2006), pp.68-69.

Note 3. From a poem translated by Talat S . Halman, in Suleyman the Magnificent Poet (Istanbul: Dost, 1987), 30-31. For a different English translation of this gazel, see Inalcik, "Sultan Süleyman: the Man and the Statesman," 99. 